\title{
CALCIUM EXTRACTION FROM ESTONIAN INDUSTRIAL WASTES BASED ON AMMONIUM SOLVENTS
}

\author{
KADRIANN TAMM, REGIINA VIIRES, REIN KUUSIK \& MAI UIBU \\ Laboratory of Inorganic Materials, Tallinn University of Technology, Tallinn, Estonia
}

\begin{abstract}
In Estonia electricity production is based mainly on local oil shale, the latter has been the country's most important mineral resources throughout the last century, up to today. In addition, the municipal solid waste incineration (MSWI) based heat and power production has developed rapidly. Industrial wastes from combustion processes are often rich in calcium and could be used as raw materials for $\mathrm{CO}_{2}$ sequestration and calcium carbonate production. Batch dissolution experiments were carried out to investigate $\mathrm{Ca}$ extraction from industrial wastes using ammonium salt solvents $\left(\mathrm{NH}_{4} \mathrm{Cl}, \mathrm{NH}_{4} \mathrm{NO}_{3}\right.$ and $\mathrm{CH}_{3} \mathrm{COONH}_{4}$ ). The dissolution equilibrium and dynamics of the main species was studied from the aspects of $\mathrm{Ca}$ extraction selectivity and environmental safety. Conductivity and $\mathrm{pH}$ change in the studied systems depends mainly on the solvent (its electrolyte ionic strength and ion mobility), addition of ashes basifies the systems. Test results indicated that $\mathrm{Ca}^{2}+$ ion extraction was noticeably enhanced by ammonium salts as compared to water systems, using $\mathrm{NH}_{4} \mathrm{NO}_{3}$ solution gave the best results (extraction degree up to 95\%). A simplified leaching mechanism for ash-solvent systems was presented, the latter can be used for future theoretical calculations. The study was focused on recovering of $\mathrm{Ca}$ from Estonian waste ashes, development of calcium carbonate as a commercial by-product will be the next step.
\end{abstract}

Keywords: oil shale ash, municipal solid waste incineration ash, precipitated calcium carbonate, utilization, $\mathrm{CO}_{2}$ sequestration.

\section{INTRODUCTION}

Republic of Estonia processes annually about 20 million tons of local fossil fuel, oil shale (OS), producing over 6 million tons of OS ash from heat and power generation as well as shale oil production [1]. Substantial waste flows are also linked with industrial processes such as municipal solid waste incinerator (MSWI) - 56,000 tons/y of bottom ash, 3,800 tons/y of fly ash (FA) and 6,500 tons/y of air pollution control (APC) residue [2]. Reuse of these wastes is currently very limited in Estonia - only 5\% of OS ashes are utilized mostly in the cement industry, the rest of it is deposited in ash fields. In addition, 11,5 $\mathrm{Mt}$ of $\mathrm{CO}_{2}$ was emitted in 2016 from the power plants, of whose OS combustion has the biggest proportion due to the high content of mineral carbonates in OS [1], [3]. Recycling of these wastes is obligatory in order to move towards circular economy.

It has been demonstrated that an OS ash-water suspension is able to bind up to $290 \mathrm{~kg}$ of $\mathrm{CO}_{2}$ per ton of ash [4]. Moreover, upgrading industrial wastes into commercial products (e.g., precipitated calcium carbonate (PCC)) [4]-[7] via the carbonation route is one of the promising directions for $\mathrm{CO}_{2}$ sequestration process. In recent years, various carbonation routes have been studied in various reactor configurations to produce PCC-type materials using both industrial ash and its leaching waters that are saturated with calcium and accompanying ions [8]-[11].

Studies have shown that $\mathrm{Ca}(\mathrm{OH})_{2}, \mathrm{CaSO}_{4} \cdot 2 \mathrm{H}_{2} \mathrm{O}$ and $\mathrm{CaS}$ are the main water-soluble $\mathrm{Ca}$ and $\mathrm{S}$ species in OS ash aqueous systems [12]. Also, OS ashes contain secondary $\mathrm{Ca}(\mathrm{Mg})-$ silicate minerals, and an amorphous Al-Si glass phase [4]. Estonian MSWI residues are hazardous solid wastes since they include heavy metals and organic pollutants in addition to metal oxides and water-soluble salts [13]. The latter influences the chemical composition of 
ash-water leachates. For PCC purity, it is essential to ensure the efficient but also selective extraction of calcium ions. It has been found that ammonium salts, $\mathrm{NH}_{4} \mathrm{Cl}, \mathrm{NH}_{4} \mathrm{NO}_{3}$ and $\mathrm{CH}_{3} \mathrm{COONH}_{4}$, solutions were the most promising solvents for selective extraction of calcium from steel slags [14].

The current study focuses on Ca extraction from OS and MSWI ashes using ammonium salt solvents. The dissolution equilibrium and dynamics of the main species was studied from the aspects of $\mathrm{Ca}$ extraction and environmental safety.

\section{METHODOLOGY}

Batch dissolution experiments were carried out to investigate $\mathrm{Ca}$ extraction from industrial ashes using ammonium salt solvents $\left(\mathrm{NH}_{4} \mathrm{Cl}, \mathrm{NH}_{4} \mathrm{NO}_{3}\right.$ and $\left.\mathrm{CH}_{3} \mathrm{COONH}_{4}\right)$ and acetic acid $\left(\mathrm{CH}_{3} \mathrm{COOH}\right)$ of $2 \mathrm{M}$ concentrations.

\subsection{Characterization of materials}

Oil shale fly ashes (CFB1, CFB2 and PF) collected from Narva Power Plants and shale oil production (Enefit 280) as well as the air pollution control residue (APC) and fly ash (FA) from municipal solid waste incineration block in Iru Power Plant were tested for $\mathrm{Ca}$ extraction. The circulating fluidized bed ashes CFB1 and CFB2 were taken from the common silo and from the first field of electrostatic precipitator at 2011 and 2016, respectively. The pulverized firing cyclone ash PF was collected in 2011, the Enefit280 fly ash and MSWI ashes in 2016. Ash samples were analysed using both X-ray fluorescence spectroscopy (XRF, Rigaku Primus II) and quantitative X-ray diffraction (XRD, Bruker D8 Advanced) methods at the Institute of Geology, University of Tartu. The contents of free lime $\left(\mathrm{CaO}_{\text {free }}\right)$ (ethylene glycol method) [15], sulfur (as sulfate) [16], total carbon (TC) (Electra CS - 580 Carbon/ Sulfur Determinator) were determined. The BET specific surface area (SSA) and the particle size distribution was determined using a Kelvin 1042 sorptometer and Horiba laser scattering particle size distribution analyser LA-950, respectively. The chemical composition as weight percentages together with the physical characteristics of the ashes are provided in Table 1.

Table 1: Characterization of industrial waste materials.

\begin{tabular}{|c|c|c|c|c|c|c|}
\hline \multirow[t]{2}{*}{ Chemical data } & \multicolumn{4}{|c|}{ Oil shale ashes } & \multicolumn{2}{|c|}{ MSWI ashes } \\
\hline & CFB1 & PF & CFB2 & Enefit 280 & APC & FA \\
\hline \multicolumn{7}{|l|}{ Experimental } \\
\hline $\mathrm{CaO}_{\text {free }}$ & 12.31 & 22.37 & 12.00 & 0.36 & 10.02 & 5.49 \\
\hline $\mathrm{CO}_{2}$ & 11.11 & 1.10 & 5.31 & 16.83 & 6.35 & 3.58 \\
\hline $\mathrm{S}_{\mathrm{SO} 4}$ & 7.90 & 5.24 & 1.93 & 2.26 & 2.49 & 1.53 \\
\hline \multicolumn{7}{|l|}{ XRD/XRF } \\
\hline $\mathrm{SiO}_{2}$ & 26.06 & 21.11 & 23.96 & 25.99 & 8.52 & 31.9 \\
\hline $\mathrm{CaO}_{\text {tot }}$ & 36.25 & 49.59 & 37.25 & 33.48 & 29.82 & 32.02 \\
\hline $\mathrm{MgO}$ & 3.94 & 3.30 & 2.43 & 1.98 & 1.81 & 3.10 \\
\hline $\mathrm{Na}_{2} \mathrm{O}$ & 0.07 & 0.04 & 0.11 & 0.09 & 19.00 & 4.61 \\
\hline $\mathrm{K}_{2} \mathrm{O}$ & 3.29 & 2.04 & 3.93 & 3.81 & 12.21 & 3.92 \\
\hline $\mathrm{CO}_{2 \max }$ & 18.95 & 15.88 & 13.47 & 17.06 & 13.19 & 7.57 \\
\hline \multicolumn{7}{|c|}{ Physical characteristic } \\
\hline $\mathrm{SSA}, \mathrm{m}^{2} \cdot \mathrm{g}^{-1}$ & 6.30 & 0.40 & 4.75 & 4.24 & 7.88 & 1.2 \\
\hline $\mathrm{d}_{\text {mean }}, \mu \mathrm{m}$ & 26.5 & 61.73 & 16.84 & 36.4 & 20.99 & - \\
\hline
\end{tabular}


The characteristics of ashes is highly dependent on the combustion technology. Of the six ashes, Enefit 280 and FA ashes are characterized by the lowest free lime $\left(\mathrm{CaO}_{\text {free }}\right)$ content, other ashes are rich in $\mathrm{CaO}_{\text {free }}(>10 \mathrm{wt} \%)$ (Table 1). The sulphur content in OS and MSWI ashes is present mainly in the form of anhydrite $\left(\mathrm{CaSO}_{4}\right)$. It has been shown that the smaller particle size of steelmaking slag, with a larger contact area available to react with the solvent, promoted $\mathrm{Ca}^{2+}$ ion extraction [17]. The OS ash leaching tests also indicated that the low leachability of calcium and sulfur species could be attributed to the coarse particle size of ash [18]-[19]. Effectiveness of the carbonisation process can be described by a maximal possible $\mathrm{CO}_{2}$ content of the sample $\left(\mathrm{CO}_{2 \max }\right)$, which indicates that highest binding capacity (basis of the $\mathrm{CO}_{2}$ and $\mathrm{CaO}$ content in the initial sample) has CFB1 ash and lowest MSWI FA.

\subsection{Experimental procedure}

All experiments with ash-solvent systems were performed at room temperature and atmospheric pressure by applying the standard batch-leaching test [20]. For kinetic studies, the leaching experiments were carried out in a laboratory-scale batch reactor with a volume of $200 \mathrm{ml}$. Ash-solvent suspensions were well-mixed, with a magnetic stirrer (700 rpm), The system $\mathrm{pH}$ (MT SevenGo $\mathrm{pH}$ ) and electrical conductivity of the suspensions (MT SevenGo Duo Pro) were monitored during the experiments. To achieve an equilibrium state, the ash/solvent (1/10) systems under study were kept in $50 \mathrm{~mL}$ centrifuge tubes sealed with airtight caps for $24 \mathrm{~h}$ in an overhead shaker (GFL 3025) at $45 \mathrm{rpm}$ throughout the experiment. The suspensions were filtered using a vacuum filter (Munktell filter paper, $100 \mathrm{~g} / \mathrm{m}^{2}$ ). The filtrates were analysed for cations, anions and heavy metals content. The content of sulfate and sulfide ions was determined using a Lovibond Spectro Direct spectrometer (barium sulfate turbidity and DPD/Catalyst methods, respectively). The cations $\left(\mathrm{Ca}^{2+}, \mathrm{Mg}^{2+}, \mathrm{Na}^{+}\right.$and $\mathrm{K}^{+}$) and heavy metals $(\mathrm{Zn}, \mathrm{Pb}, \mathrm{Cd}$ and $\mathrm{Cr}$ ) were determined by atomic absorption spectroscopy (Carl Zeiss Jena AAS IN: Verian Spectra AA 55B).

\section{RESULTS}

\subsection{Solubility results in ash-solvent systems}

The $\mathrm{pH}$, conductivity, and the concentration of the main species in the liquid phase was determined in ash-solvent equilibrium systems (1/10 and 1/50) by varying the type of ash as well as the solvent.

\subsubsection{Systems $\mathrm{pH}$}

It has been shown that extraction efficiency is not the only factor to affect the process, the favourable $\mathrm{pH}$ conditions crucial to guarantee the carbonisation efficiency in the final step [21].

The $\mathrm{pH}$ of systems were measured before and after extraction to detect the $\mathrm{pH}$ change (Fig. 1). The analysis results indicated that $\mathrm{Ca}$ concentration increased with the solid to liquid ratio from $1 / 50$ to $1 / 10$ up to $25000 \mathrm{mg} / \mathrm{L}$ in acidic acid systems and ranged between 1000 $4000 \mathrm{mg} / \mathrm{L}$ in ammonium salt systems. The changes in water systems were less noticeable (up to $500 \mathrm{mg} / \mathrm{L}$ ) due to much lower solubility of portlandite in water. Increasing $\mathrm{S} / \mathrm{L}$ ratio to1/5 in OS ash-water systems had no effect in Ca leaching [12].

The average $\mathrm{pH}$ increase in $1 / 10$ ash $-\mathrm{NH}_{4} \mathrm{Cl}$ and ash- $\mathrm{NH}_{4} \mathrm{NO}_{3}$ systems were $<5$ units, and for acetate systems $<3$ units, almost twice the growth. Thus, the final $\mathrm{pH}$ of the ash-solvent system was rather affected by the selected solvent than the characteristics of the ash. 


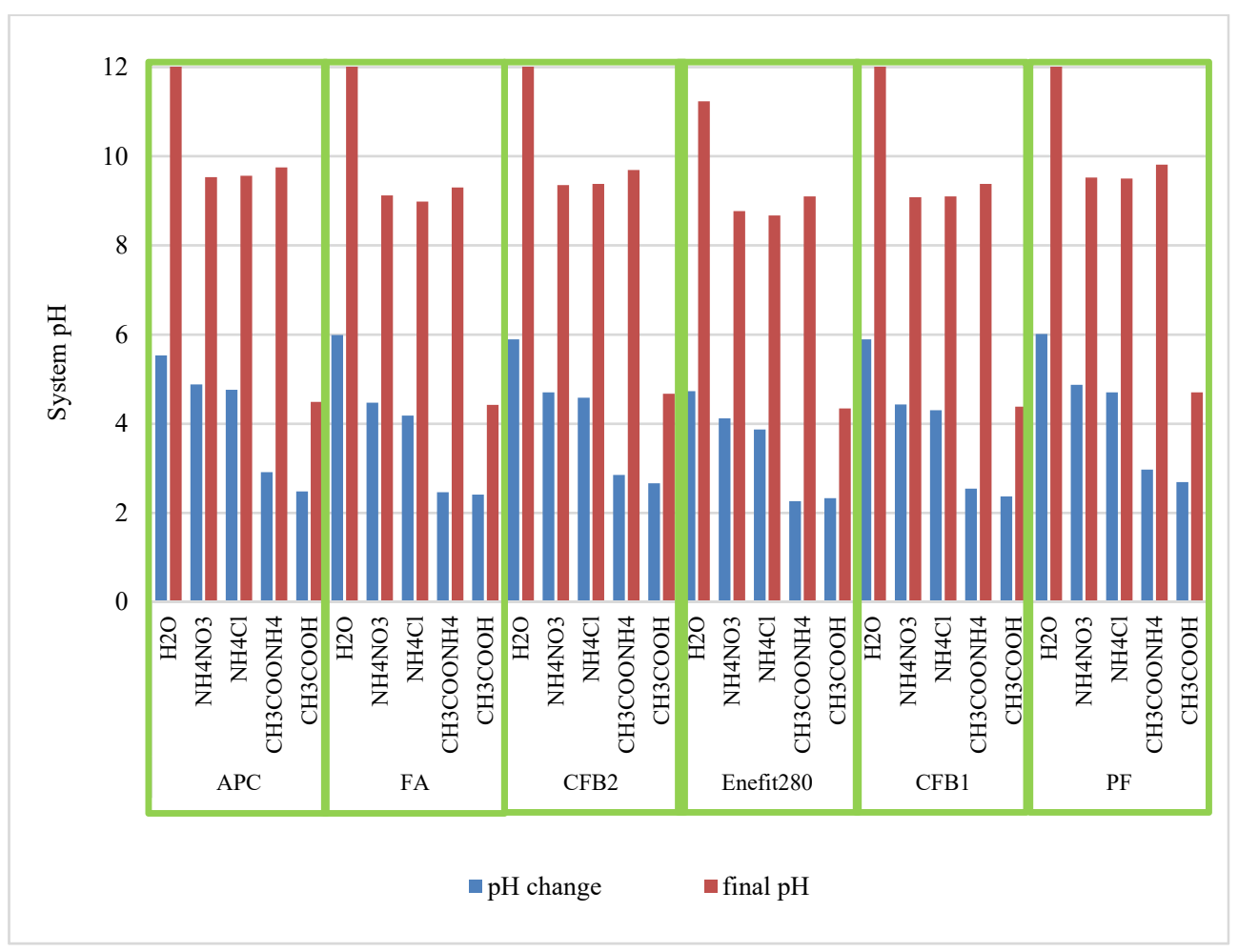

Figure 1: The $\mathrm{pH}$ of $24 \mathrm{~h}$ ash/solvent (1/10) system.

The lowest $\mathrm{pH}$ was determined in Enefit280-solvents systems, in which case the ash contained the lowest amount of $\mathrm{CaO}_{\text {free }}$ was lower (Table 1).

For all ash-solvent system $\mathrm{pH}$ was noticeably lower than for ash-water systems $(\mathrm{pH} \sim 12)$, which may affect the further carbonisation process.

\subsubsection{Systems EC}

When ash was immersed info ammonium salt solvent, the electrical conductivity (EC) decreased as, shown in eqn. (1)-(3), mobile hydroxonium ions $\left(349.8 \mathrm{~S} \cdot \mathrm{cm}^{2} / \mathrm{mol}\right)$ are replaced by less mobile ions, (e.g. $\mathrm{Ca}^{2+}$ ion $\left(59.5 \mathrm{~S} \cdot \mathrm{cm}^{2} / \mathrm{mol}\right)$ or $\mathrm{OH}^{-}$ion $\left(198.3 \mathrm{~S} \cdot \mathrm{cm}^{2} / \mathrm{mol}\right.$ [23]). In acetic acid systems, the dissolved ion content and interactions are small, with the addition of ash the electrical conductivity increased because the weakly dissociated acid is replaced by the highly dissociated compounds during neutralization. 


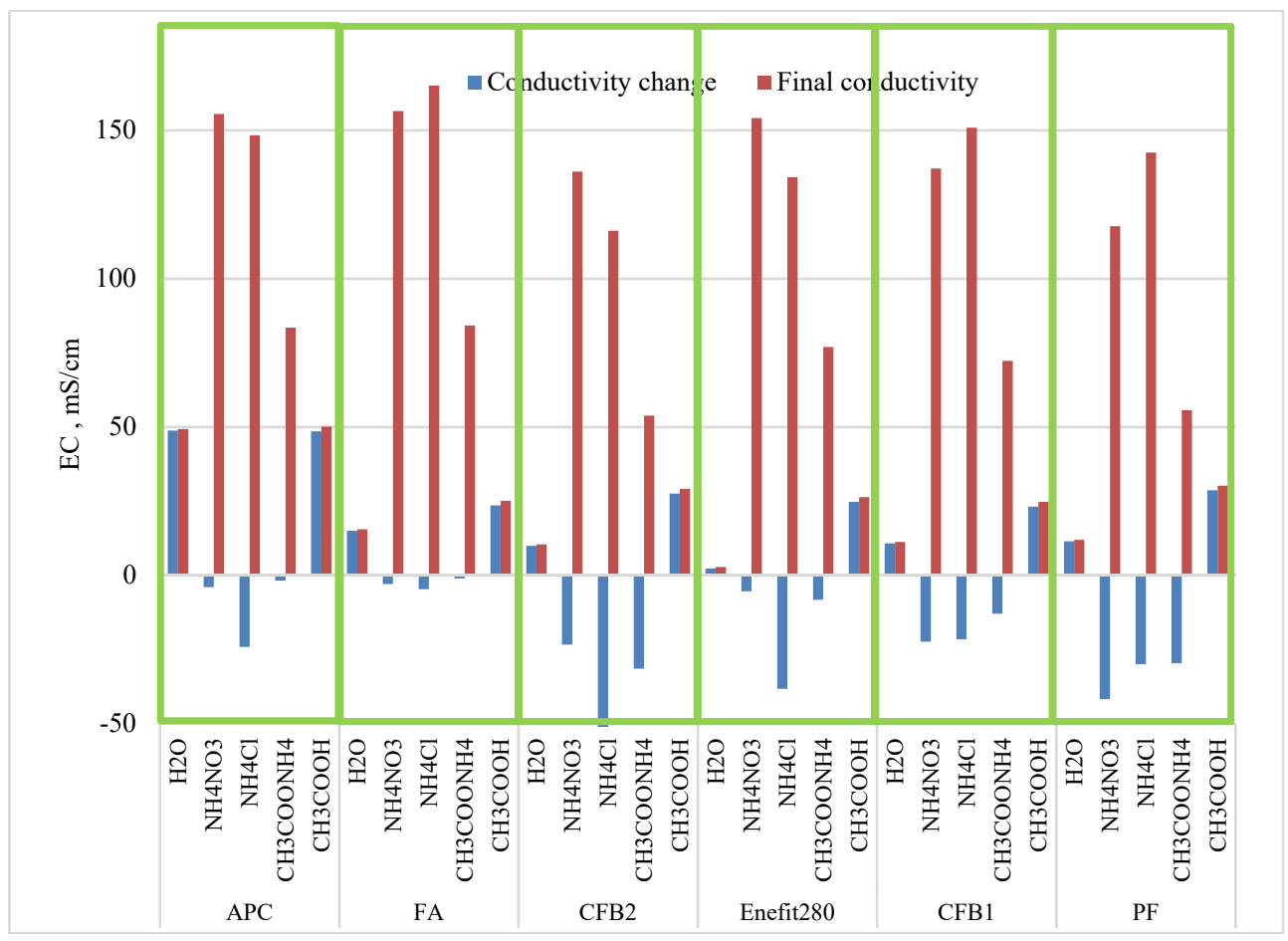

Figure 2: Electrical conductivity of $24 \mathrm{~h}$ ash/solvent (1/10) system.

The electrical conductivity was higher in case of all the selected solvents as compared to ash-water systems, even for APC ash-solvent systems, which contained mainly water-soluble Ca compounds $\left(\mathrm{Ca}(\mathrm{OH})_{2}, \mathrm{CaCl}(\mathrm{OH}), \mathrm{CaO}\right)$.

3.1.3 Leachability of cations and anions in ash-solvent systems

From the aspect of PCC purity, it essential to investigate the leaching of dissolvable species in ash-solvent systems.

Using acidic acid resulted highest the concentration of $\mathrm{Ca}^{2+}$ ions in the filtrate $(32000 \mathrm{mg} / \mathrm{L})$, but the concentration of cations $\left(\mathrm{Mg}^{2+}, \mathrm{K}^{+}\right.$and $\left.\mathrm{Na}^{+}\right)$and anions $\left(\mathrm{SO}_{4}{ }^{2-}, \mathrm{S}^{2-}\right.$, $\mathrm{Cl}^{-}, \mathrm{SiO}_{2}$ ) was also high (Fig. 3 and Fig. 4). Also, the CFB2 leachate contained heavy metals $\mathrm{Zn}$ and $\mathrm{Pb}, 56.8$ and $5.12 \mathrm{mg} / \mathrm{L}$, respectively.

When ammonium solvents were used, the Ca concentration (up to $20000 \mathrm{mg} / \mathrm{L}$ ) was higher as compared to ash-water systems but the leaching of other components was inhibited (except for sodium and potassium). All of the ash-solvent filtrates contained $\mathrm{Mg}^{2+}$ ions, unlike ash-water systems, where the concentration of magnesium ion was negligible. 


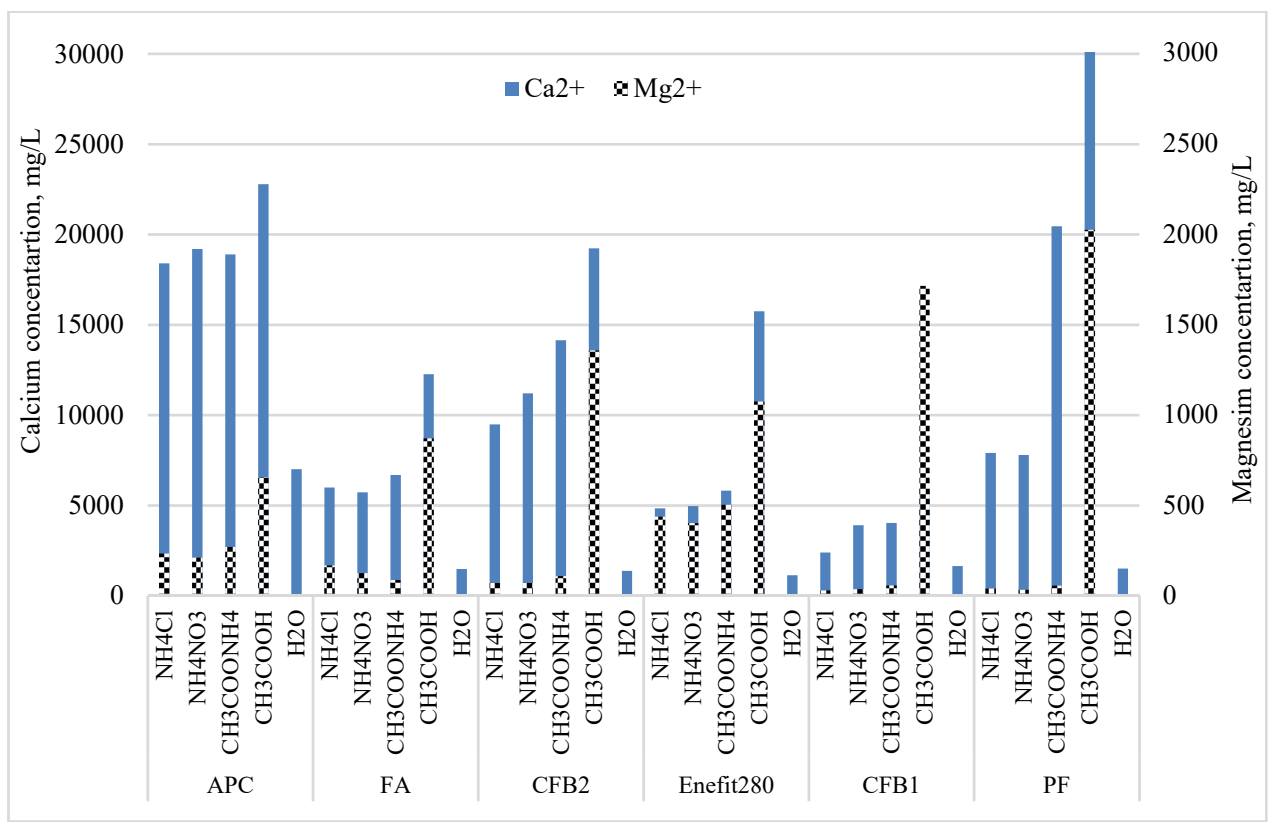

Figure 3: Concentration of $\mathrm{Ca}^{2+}$ and $\mathrm{Mg}^{2+}$ ions in $24 \mathrm{~h}$ ash-solvent systems.

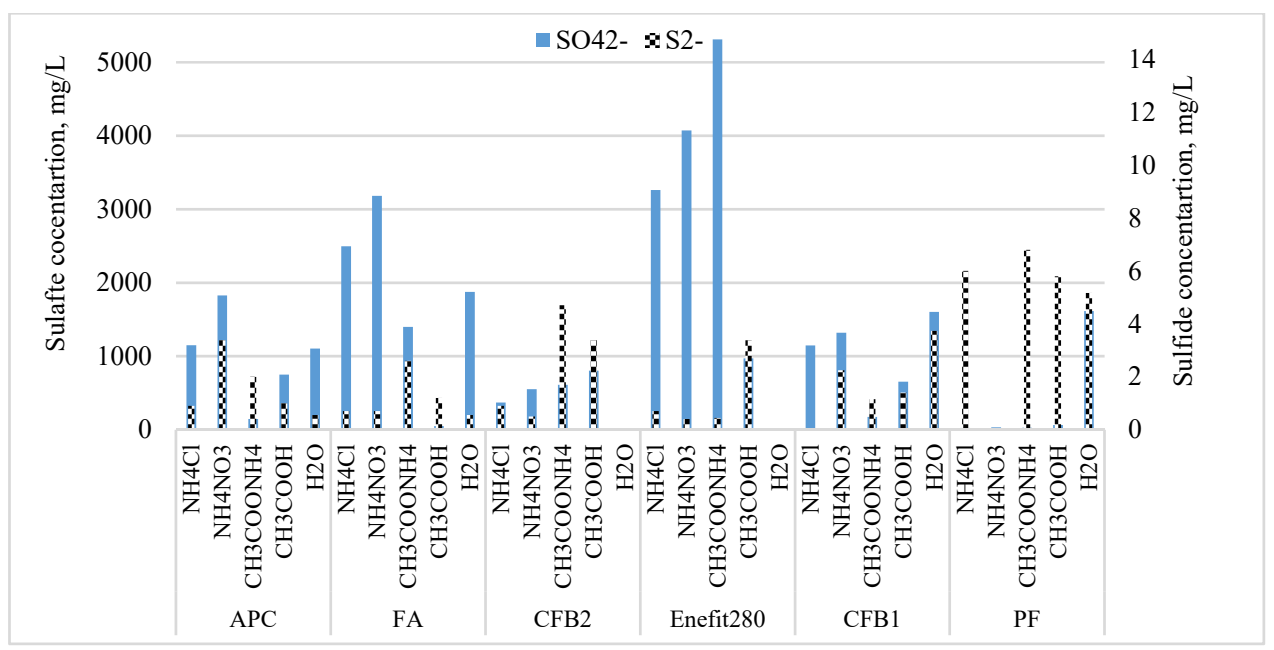

Figure 4: Concentration of sulfur ions in $24 \mathrm{~h}$ ash-solvent systems.

The results indicated that calcium could be selectively extracted from OS and MSWI ashes using ammonium solvents. 


\subsection{Dissolution kinetics in ash-solvent systems}

The main characteristics of the Ca dissolution process for OS ashes and the dissolution kinetics of main water-soluble Ca-compounds together with the dissolution mechanism has been described in previous studies [12], [24], [25].

As the system $\mathrm{pH}$ and electrical conductivity had similar changing dynamics in case of all selected ashes indicating that the main changes occurred in 1 minutes, the main results are shown based on CFB OS ash on Fig. 5, Fig. 6, Fig. 7 and Fig. 8.

As the ash was contacted with the solvent, dissociation of the compounds occurred immediately leading to the increase in hydroxide ions concentration expressed in the rapid $\mathrm{pH}$ increase of the suspension.

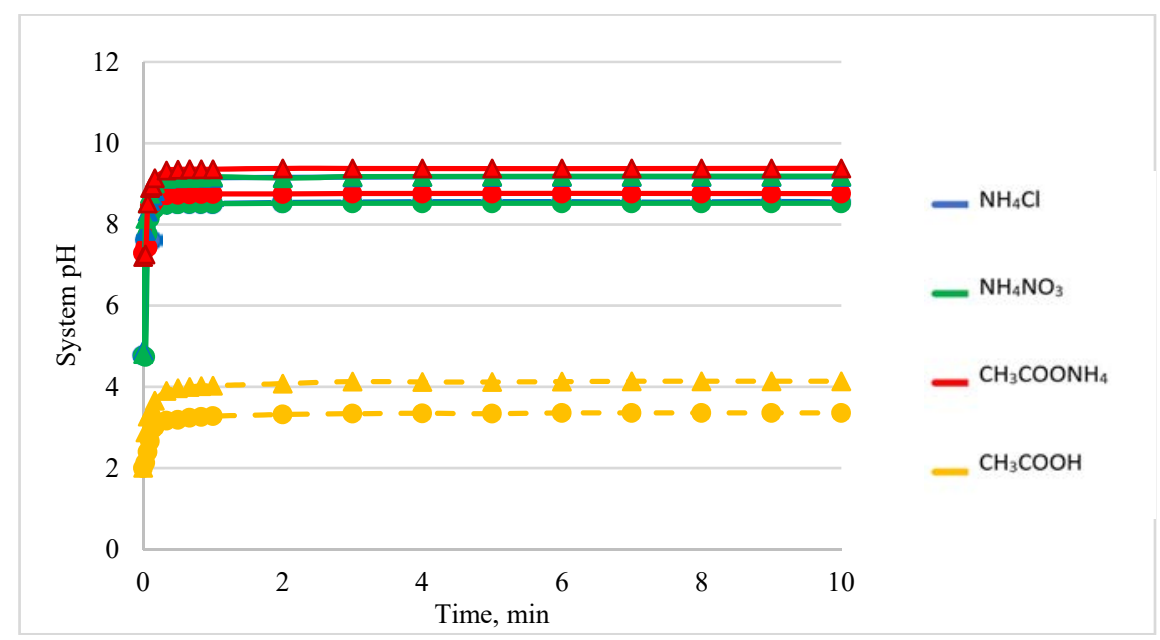

Figure 5: The $\mathrm{pH}$ change of CFB OS ash-solvent system $\mathrm{pH}$ up to 10 minutes $1 / 10(\Delta)$ and $1 / 50(\bullet)$.

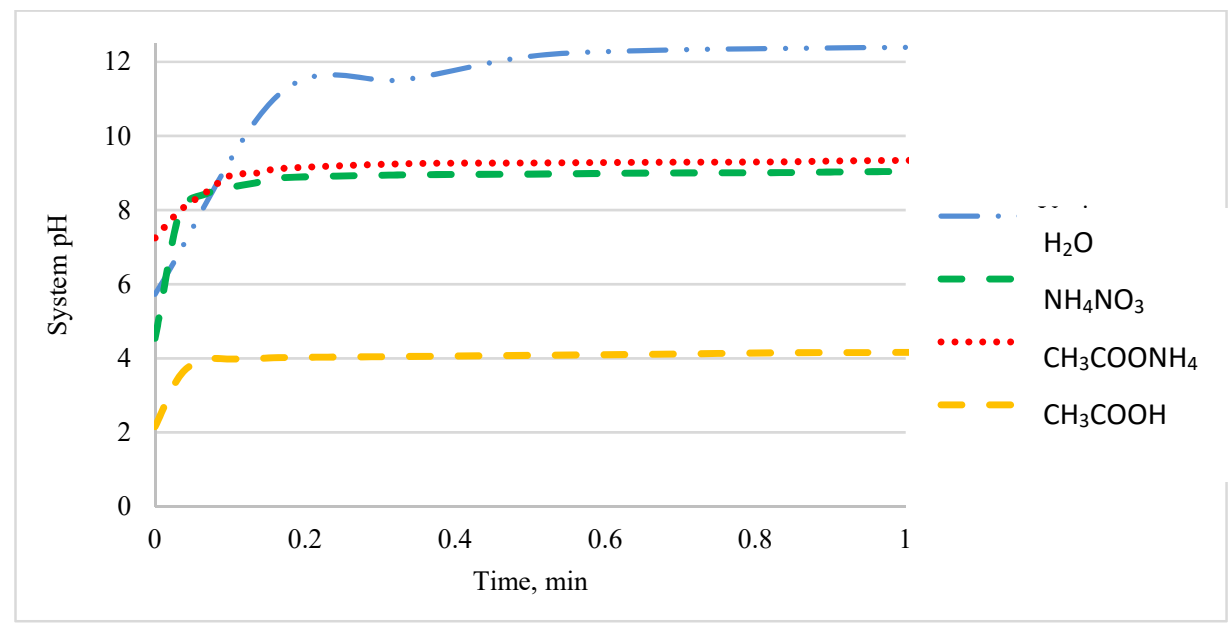

Figure 6: Changes in system pH for CFB OS ash-solvent system during 1 minute. 


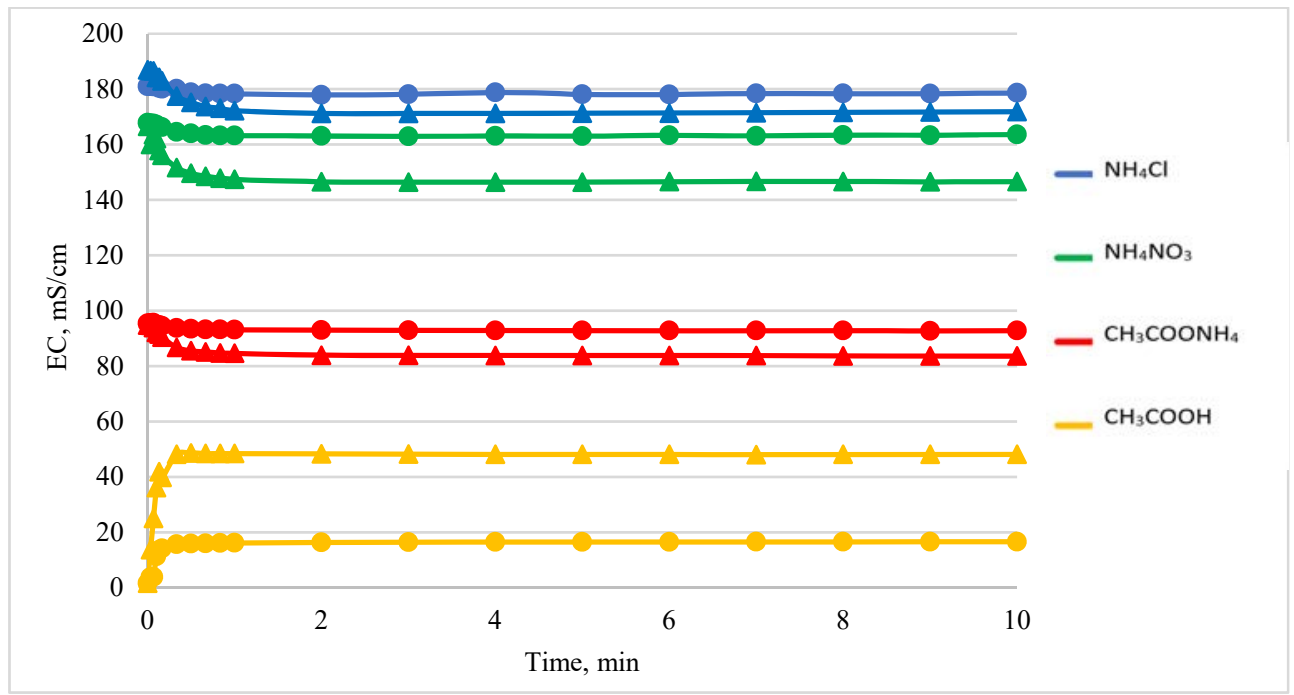

Figure 7: Changes in electrical conductivity for CFB OS ash-solvent during 10 minutes $1 / 10(\Delta)$ and $1 / 50(\bullet)$.

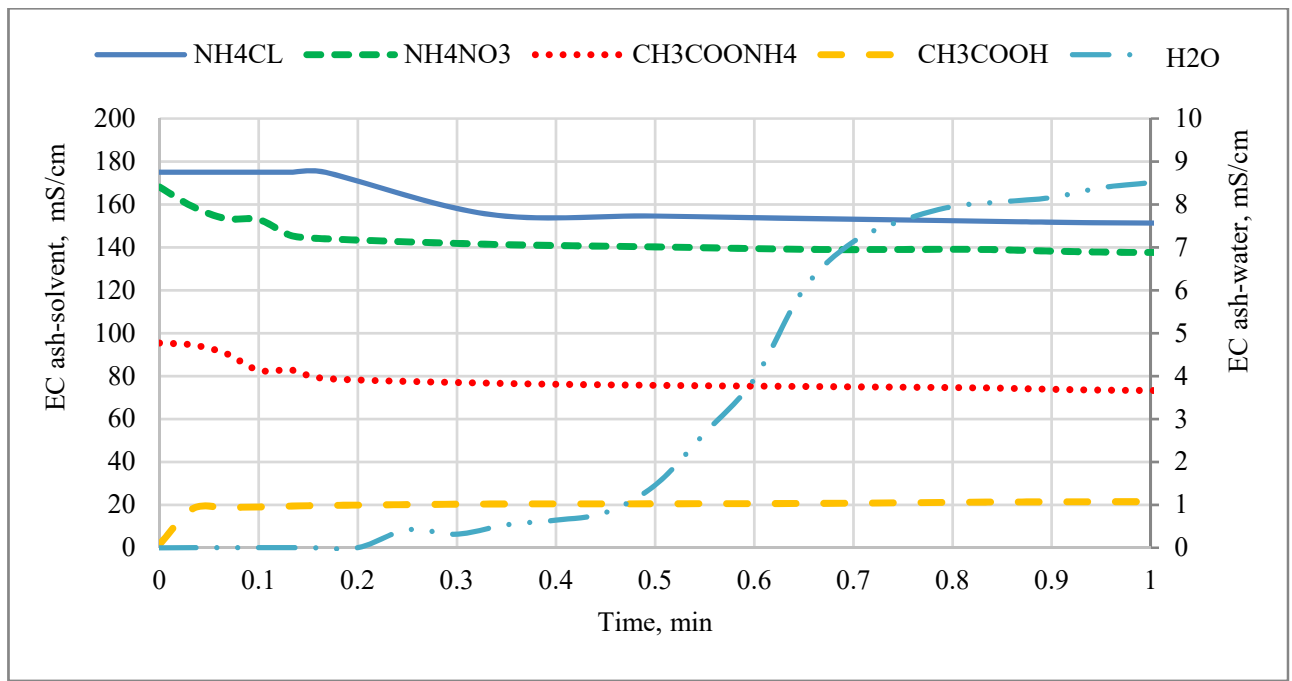

Figure 8: Changes in electrical conductivity for CFB OS ash-solvent systems during 1 minute.

Calcium extraction reactions were completed within 1 minute, $\mathrm{pH}$ and conductivity change plateaued already in 10 minutes (Fig. 5 and Fig. 7). Using ammonium salt solutions induces a rapid decrease in electrical conductivity, as the use of acetic acid solution leads to its increase (Fig. 8). 
The changes in electrical conductivity and $\mathrm{pH}$ in studied systems mainly depends on the solvent $\left(\mathrm{NH}_{4} \mathrm{Cl}, \mathrm{NH}_{4} \mathrm{NO}_{3}, \mathrm{CH}_{3} \mathrm{COONH}_{3}\right.$, concentration $2 \mathrm{M}$, its electrolyte ionic strength and ion mobility), addition of ashes basifies the systems.

\subsection{Process chemistry}

Eqns (1)-(4) represent a simplified dissociation for ash-solvent systems:

$$
\begin{aligned}
& \mathrm{NH}_{3}+\mathrm{Cl}^{-}+\mathrm{H}_{3} \mathrm{O}^{+}+\mathrm{CaO} \rightleftarrows \mathrm{NH}_{4}^{+}+2 \mathrm{OH}^{-}+\mathrm{Cl}^{-}+\mathrm{Ca}^{2+} . \\
& \mathrm{NH}_{3}+\mathrm{NO}_{3}^{-}+\mathrm{H}_{3} \mathrm{O}^{+}+\mathrm{CaO} \rightleftarrows \mathrm{NH}_{4}^{+}+\mathrm{OH}^{-}+\mathrm{NO}_{3}^{-}+\mathrm{Ca}^{2+} . \\
& \mathrm{NH}_{3}+\mathrm{CH}_{3} \mathrm{COO}^{-}+\mathrm{H}_{3} \mathrm{O}^{+}+\mathrm{CaO} \rightleftarrows \mathrm{NH}_{4}^{+}+2 \mathrm{OH}^{-}+\mathrm{CH}_{3} \mathrm{COO}^{-}+\mathrm{Ca}^{2+} . \\
& \mathrm{CH}_{3} \mathrm{COO}^{-}+\mathrm{H}_{3} \mathrm{O}^{+}+\mathrm{CaO} \rightleftarrows \mathrm{CH}_{3} \mathrm{COO}^{-}+\mathrm{Ca}^{2+}+2 \mathrm{H}_{2} \mathrm{O} .
\end{aligned}
$$

$\mathrm{CaO}$ represents all water-soluble $\mathrm{Ca}$ regardless of the actual form in which it is initially bound. The two-weak base - strong acid salts (ammonium chloride and ammonium nitrate) eqns (1) and (2), a salt of a weak base and weak acid (ammonium acetate) eqn (3) and weak acid (acetic acid), eqn (4) represents the equilibriums states. This simplified ash-solvent leaching process chemistry can be used for future theoretical calculations.

\subsection{Ca extraction efficiency}

As shown in paragraph 3.3, the $\mathrm{pH}$ and electrical conductivity stabilised already during 10 minutes of contact, also the Ca extraction efficiencies remained constant after 10 minutes. The calcium ion extraction efficiencies for different solvents are shown in Fig. 9. For all ashes at $1 / 10$ solid to liquid ratio the extraction efficiencies were higher with ammonium salt and acetic acid solvents compering water in all six ash systems.

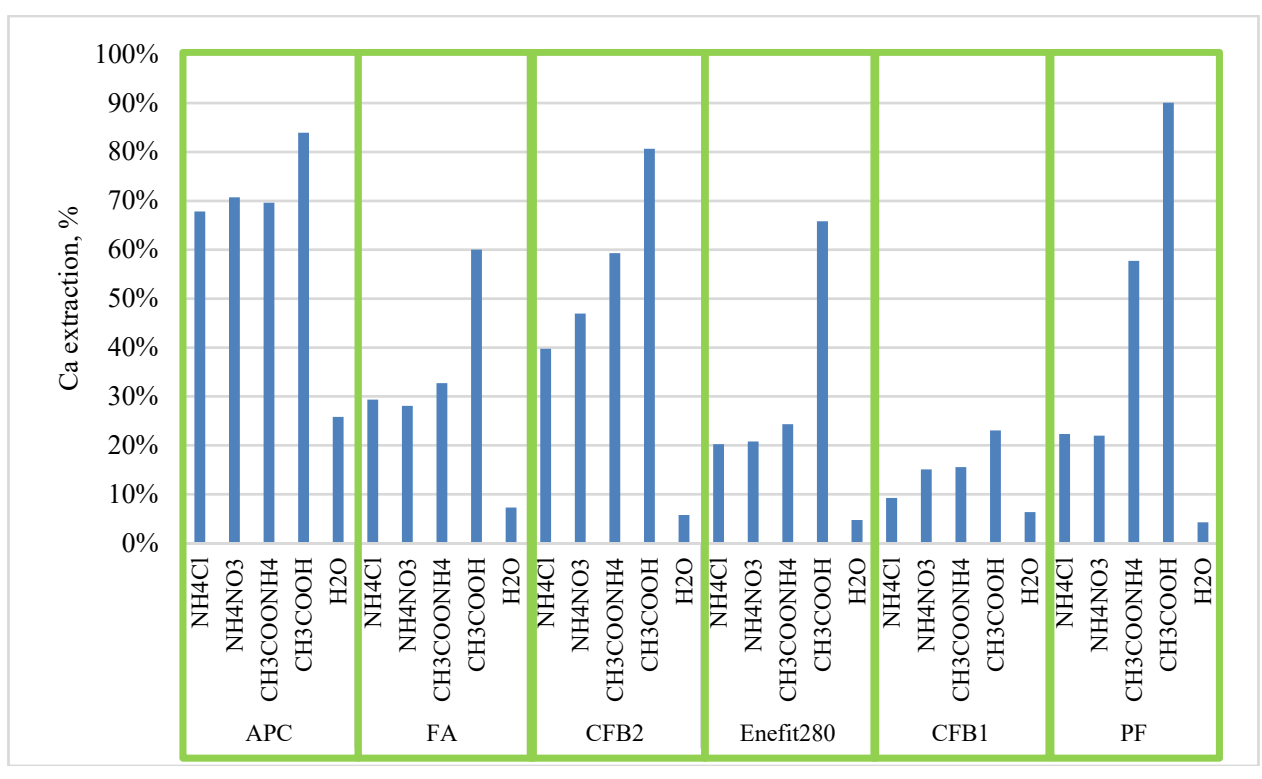

Figure 9: Ca extraction efficiency according to solvent type. 


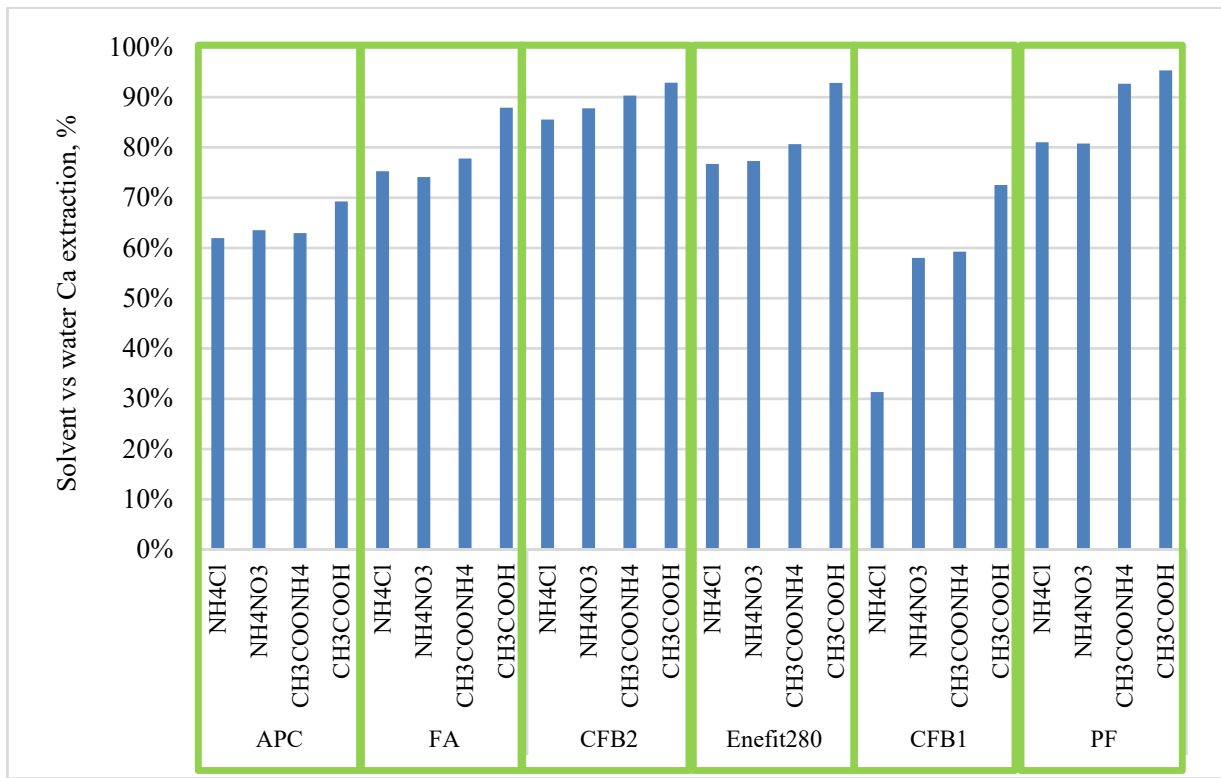

Figure 10: Ammonium salts and acetic acid solvents vs water $\mathrm{Ca}$ extraction.

The extraction efficiency for ammonium salt solvents appeared to be in the same range in different ash systems (Fig. 9), about 70\% in APC systems, 30\% in FA systems, 50\% in CFB2 systems, $21 \%$ in Enefit 280, 15\% in CFB1 and up to 50\% in PF systems. The calcium was extracted most efficiently with acetic acid, up to $90 \%$, however other species were detected in the filtrate as well, which could react with $\mathrm{CO}_{2}$ and reduce the purity of PCC.

Comparing the extraction efficiency of ammonium salts and acetic acid solvents with water based systems, it was indicated that Ca extraction efficiency could be increased by $95 \%$ (Fig. 10). According to the main characteristics of initial ashes, e.g. $\mathrm{CaO}$ content, SSA, particle size, other water dissolved species, using CFB2 ash gave the best results.

\section{CONCLUSION}

Industrial wastes from combustion processes are often rich in calcium and could be used as feedstock for $\mathrm{CO}_{2}$ sequestration and following calcium carbonate production. In order to use industrial wastes from combustion processes for $\mathrm{CO}_{2}$ sequestration and further carbonisation, understanding the principles of $\mathrm{Ca}$ extraction is crucial. Batch dissolution experiments were carried out to investigate $\mathrm{Ca}$ extraction from OS and MSWI ashes using ammonium salt solvents. The dissolution equilibrium and dynamics of the main species was studied from the aspects of $\mathrm{Ca}$ extraction selectivity and environmental safety.

Results were compared with the previously studied ash - water systems. The system electrical conductivity and $\mathrm{pH}$ were continuously measured in order to follow the kinetics. The changes in respective indicators mainly depend on the solvent type $\left(\mathrm{NH}_{4} \mathrm{Cl}, \mathrm{NH}_{4} \mathrm{NO}_{3}\right.$, $\mathrm{CH}_{3} \mathrm{COONH}_{3}$, concentration $2 \mathrm{M}$, its electrolyte ionic strength and ion mobility), addition of ashes basifies the systems.

Test results indicated that $\mathrm{Ca}^{2+}$ ion extraction was noticeably enhanced by ammonium salts solutions as compared to water based systems, using $\mathrm{NH}_{4} \mathrm{NO}_{3}$ solution gave the best 
results (extraction degree up to 90\%). A simplified leaching mechanism for ash-solvent systems was presented, the latter can be used for future theoretical calculations.

This work examined the extraction of the $\mathrm{Ca}^{2+}$ ion as the first step of the complex mineral waste utilisation process. These results would serve as basis for the further studies, which focus on the carbonisation processes of the respective extracts and its effect on process conditions and the quality of PCC as commercial product.

\section{ACKNOWLEDGEMENTS}

The Estonian Ministry of Education and Research IUT33-19 and KIK17083 supported this study financially. The article was published with the support of European Union via the European Regional Development Fund.

[1] Eesti Energia Annual Report 2016 Online, www.energia.ee//doc/8457332/ettevottest/investorile/pdf/annual_report_2016_est.pdf. Accessed on: 18 Jun. 2017.

[2] Petrov, A., Eesti Energia AS Iru Elektrijaama Keskkonnaaruanne, 2015 Online, www.keskkonnaagentuur.ee/sites/default/files/iru_keskkonnaaruanne_2015.pdf. Accessed on: 18 Jun. 2017 (in Estonian).

[3] Ots, A., Oil Shale Fuel Combustion, Tallinn University of Technology Press, Tallinn, 2006.

[4] Uibu, M., Kuusik, R., Andreas, L. \& Kirsimäe, K., The $\mathrm{CO}_{2}$-binding by Ca-Mgsilicates in direct aqueous carbonation of oil shale ash and steel slag. Energy Procedia, 4, pp. 925-932, 2011.

[5] Uibu, M., Velts, O. \& Kuusik, R., Developments in $\mathrm{CO}_{2}$ mineral carbonation of oil shale ash. Journal of. Hazardous Material, 174, pp. 209-214, 2010.

[6] Van Gerven, T., Van Keer, E., Arickx, S., Jaspers, M., Wauters, G. \& Vandecasteele, C., Carbonation of MSWI-bottom ash to decrease heavy metal leaching, in view of recycling. Waste Manage, 25, pp. 291-300, 2005.

[7] Costa, G., Baciocchi, R., Polettini, A., Pomi, R., Hills, C. D. \& Carey, P. J., Current status and perspectives of accelerated carbonation processes on municipal waste combustion residues. Environmental Monitoring and Assessment, 135, pp. 55-75, 2007.

[8] Teir, S. Eloneva, S. \& Zevenhoven, R. Production of precipitated calcium carbonate from calcium silicates and carbon dioxide. Energy Conversion and Management, 46, pp. 2954-2979, 2005.

[9] Velts, O., Uibu, M., Kallas, J. \& Kuusik, R., Waste oil shale ash as a novel source of calcium for precipitated calcium carbonate: Carbonation mechanism, modelling and product characterization. Journal of. Hazardous Material, 195, pp. 139-146, 2011.

[10] Velts, O., Kindsigo, M., Uibu, M., Kallas, J. \& Kuusik, R., $\mathrm{CO}_{2}$ mineralisation: Production of $\mathrm{CaCO}_{3}$-type material in a continuous flow disintegrator-reactor. Energy Procedia, 63, pp. 5904-5911, 2015.

[11] Tamm, K., Kallas, J., Kuusik, R. \& Uibu M., Modelling continuous process for precipitated calcium carbonate production from oil shale ash. Energy Procedia, 2017.

[12] Tamm, K., Kallaste, P., Uibu, M., Kallas, J., Velts-Jänes, O. \& Kuusik, R. Leaching Thermodynamics and Kinetics of Oil Shale Waste Key Components. Oil Shale, 33(1), pp. 80-99, 2016. 
[13] Berber, H., Frey, R. Voronova, V. \& Koroljova A., A feasibility study of municipal solid waste incineration fly ash utilisation in Estonia, Waste Management and Research, 2017.

[14] Eloneva, S., Said, A., Fogelholm, C.J. \& Zevenhoven, R., Preliminary assessment of a method utilizing carbon dioxide and steelmaking slags to produce precipitated calcium carbonate. Applied Energy, 90, pp. 329-334, 2011.

[15] Reispere, H.J., Determination of free CaO content in oil shale ash, Transact. Tallinn Polytechnical Institute, series A, 245, pp. 73-76, 1966 (in Estonian).

[16] EVS 664:1995. Solid Fuels. Sulphur content. Determination of total sulphur and its bonding forms.

[17] Lekakh, S.N., Rawlins, C.H., Robertson, D.G.C., Richards, V.L. \& Peaslee, K.D., Kinetics of Aqueous Leaching and Carbonization of Steelmaking Slag, Metallurgical and Materials Transactions, B39, pp. 125-134, 2008.

[18] Irha, N., Uibu, M., Jefimova, J., Raado, L., Hain, T. \& Kuusik R., Leaching behaviour of Estonian oil shale ash-based construction mortars. Oil Shale, 31(4), pp. 394-411, 2014.

[19] Tamm, K., Kuusik, R., Uibu, M. \& Kallas, J., Transformations of sulfur compounds in oil shale ash suspension. WIT Transactions on Ecology and the Environment, vol. 163, WIT press: New Forest, UK, pp. 25-33, 2012.

[20] European standard EN 12457-2:2002. Characterization of Waste - Leaching Compliance test for leaching of granular waste materials and sludges - Part 2, European Committee for Standardization, Brussels, 2003.

[21] Eloneva, S., Teir, S., Revitzer, H., Salminen, J., Said, A., Fogelholm, C.J. \& Zevenhoven, R., Reduction of $\mathrm{CO}_{2}$ Emissions from Steel Plants by Using Steelmaking Slags for Production of Marketable Calcium Carbonate, Process Metallurgy, 80(6), pp. 415-421, 2009.

[22] Kim, M.J., Pak, S.Y., Kim. D. \& Jung S., Optimum Conditions for Extracting Ca from CKD to Store $\mathrm{CO}_{2}$ Through Indirect Mineral Carbonation, KSCE Journal of Civil Engineering, 21(3) pp. 629-635, 2017.

[23] Kreshkov, A.P., Fundamentals of Analytical Chemistry, 3, 1970 (in Russian).

[24] Uibu, M., Tamm, K., Velts-Jänes, O., Kallaste, P., Kuusik, R. \& Kallas, J., Utilization of oil shale combustion wastes for PCC production: Quantifying the kinetics of $\mathrm{Ca}(\mathrm{OH})_{2}$ and $\mathrm{CaSO}_{4} \cdot 2 \mathrm{H}_{2} \mathrm{O}$ dissolution in aqueous systems. Fuel Processing Technology, 140, pp. 156-164, 2015.

[25] Tamm, K., Uibu, M., Kallas, J., Kallaste, P., Velts-Jänes, O. \& Kuusik, R., Thermodynamic and kinetic study of $\mathrm{CaS}$ in aqueous systems. Fuel Processing Technology, 142, pp. 242-249, 2016. 